\title{
SUROWOŚĆ CZY MILOSIERDZIE? POSTAWA CYPRIANA Z KARTAGINY WOBEC PROBLEMÓW OSÓB DUCHOWNYCH NA PODSTAWIE JEGO KORESPONDENCJI
}

\author{
Rigidity or mercy? The attitude of Cyprian of Carthage towards the problems \\ of the clergy based on his correspondence
}

\begin{abstract}
The problems of the clergy, raised in the letters of St. Cyprian, Bishop of Carthage $(+258)$, concerned: involvement in material matters, violation of the vow of chastity, abuses against the Eucharist, disobedience to superiors, and insufficient care for the poor. In most cases, he made decisions combining rigidity and mercy. He gave a chance for conversion through penance, and only when this did not work, did he proceed to the penalty of exclusion from the Church. While he was ruthlessly rigorous with clergymen involved in inheritance affairs, which was connected with the strict African synodal law, he treated the behaviour of the Aquarians, by contrast, as a mere stupidity, deserving forgiveness.
\end{abstract}

Keywords: Cyprian, North Africa, mercy, rigidity, clergy, charity, heresies

\section{Streszczenie}

Problemy duchowieństwa, poruszane w listach św. Cypriana, biskupa Kartaginy (+ 258) dotyczyły: angażowania się w sprawy materialne, łamania ślubu czystości, nadużyć przy sprawowaniu eucharystii, braku posłuszeństwa przełożonym, niewystarczającej troski o biednych. W większości spraw podejmował on decyzje łączące postawy surowości i miłosierdzia. Dawał szansę nawrócenia przez pokutę, a dopiero gdy to nie przynosiło skutku, posuwał się do kary wyłączenia z Kościoła. Był jednak bezlitosnym rygorystą wobec duchownych angażujących się w sprawy spadkowe, co wiązało się z surowym afrykańskim prawem synodalnym. Natomiast postępowanie akwarian traktował jako zwykłą głupotę, zasługującą na wybaczenie.

Słowa klucze: Cyprian, Afryka Północna, miłosierdzie, surowość, duchowieństwo, działalność charytatywna, herezje

Ks. Mariusz Szram, profesor nauk teologicznych, kierownik Katedry Patrologii Greckiej i Łacińskiej na Wydziale Teologii KUL, wykładowca patrologii i języków klasycznych, specjalista w zakresie teologii patrystycznej, szczególnie egzegezy, chrystologii i eschatologii Orygenesa; e-mail: m.szram@wp.pl. 
$\mathrm{G}^{\mathrm{s}}$ łówny przedmiot korespondencji św. Cypriana (ok. 200-258) stanowią: spór wokół lapsi, problemy związane z ponownym przyjęciem ich na łono Kościoła oraz zagadnienie powtórnego chrztu heretyków, a także schizmy Felicissima, Nowacjana i Nowata ${ }^{2}$. Dobrze znana jest postawa biskupa w pierwszej z tych kwestii, łącząca miłosierdzie wobec upadłych z wymaganiami surowej pokuty, będącej warunkiem powrotu do kościelnej wspólnoty. Natomiast rzadko zwraca się uwagę na fakt, że biskup Kartaginy z racji pełnionego urzędu zajmował stanowisko również w innych sprawach duszpasterskich, dotyczących głównie osób duchownych ${ }^{3}$. Analiza listów związanych z tą problematyką pozwoli stwierdzić, czy Cyprian w swoich decyzjach łączył surowość z miłosierdziem, jak w przypadku problemów z lapsi, czy może w niektórych sytuacjach jedna z tych postaw przeważała.

Punktem wyjścia do przedstawienia powyższych kwestii może być diagnoza stanu moralnego kartagińskiego duchowieństwa, jaką postawił sam Cyprian w 250 r. w dziele De lapsis, w opisie niewątpliwie prawdziwym, chociaż nie stroniącym od retorycznej emfazy, przejawiającej się w nagromadzeniu obok siebie określeń różnych złych czynów: „Zabiegali poszczególni o pomnożenie majątku, a zapomniawszy, co czynili wierni przedtem, w czasach apostolskich, albo co zawsze czynić winni, z nienasyconym żarem żądzy zabierali się do powiększania mienia. Nie ma u kapłanów pobożności, nie ma u niższych duchownych nieskażonej wiary, nie ma w uczynkach miłosierdzia, nie ma w obyczajach karności (Non in sacerdotiis religio devota, non in ministeriis fides integra, non in operibus misericordia, non in moribus disciplina)" 4 .

Niektóre z powyższych zaniedbań były przedmiotem konkretnych interwencji biskupa Kartaginy opisanych w jego korespondencji. Przedstawię kilka najważniejszych spraw związanych z postępowaniem duchownych, pojawiających się w listach Cypriana, i postaram się ocenić, na ile biskup Kartaginy kierował się w ich rozwiązaniu surowością, a na ile miłosierdziem, i co o tym mogło decydować.

\section{1. „Nie zasługuje, aby przy ołtarzu Boga był wymieniany w modlitwie kapłańskiej ten, kto od ołtarza chciał odwoływać kapłanów i inne sługi Boże"5}

Listy Cypriana są świadectwem jego troski nie tylko o duchownych i wiernych świeckich mieszkających w Kartaginie, ale także w innych ośrodkach północnej Afryki. Akceptował on władzę biskupów nad ich lokalnymi Kościołami, ale uważał za normalne zjawisko udzielanie wspomagających konsultacji także poza regularnie odbywającymi się synodami biskupów

\footnotetext{
2 Por. Cyprianus, Epistulae 15-61, 68-75. Zob. J. Grzywaczewski, Great Persecutions and the Reconciliation of the Lapsi, Warszawa 2015, s. 100-135.

3 Por. M. Michalski, Wstęp, w: Św. Cyprian, Listy, tłum. W Szołdrski, Warszawa 1969, „Pisma Starochrześcijańskich Pisarzy” (dalej PSP), t. 1, s. 10; J. Czuj, Święty Cyprian na tle epoki, „Ateneum Kapłańskie”, 36/1935, s. 113-135; M. Bogucki, Problemy duszpasterskie w listach św. Cypriana, „Studia Theologica Varsaviensia”, 9/1971, nr 1, s. 191-224; P.J. Fitzgerald, A Model for Dialogue: Cyprian of Carthage on Ecclesial Discernment, „Theological Studies", 59/1998, s. 249.

4 Por. Cyprianus, De lapsis 6, wyd. G. Hartel, Wien 1868, „Corpus Scriptorum Ecclesiasticorum Latinorum” (dalej CSEL), t. 3/1, s. 240; Cyprian, O upadłych, tłum. J. Czuj, Poznań 1937, „Pisma Ojców Kościoła” (dalej POK), t. 19, s. 199-200. Zob. A.G. Hamman, Życie codzienne w Afryce Pólnocnej w czasach św. Augustyna, thum. M. Stafiej-Wróblewska, E. Sieradzińska, Warszawa 1989, s. 22.

5 Cyprianus, Epistula 1, 2, wyd. G. Hartel, Wien 1871, CSEL 3/2, s. 466; Św. Cyprian, Listy, tłum. W. Szołdrski, Warszawa 1969, PSP 1, s. 28.
} 
afrykańskich $^{6}$ i przesyłał drogą korespondencyjną pouczenia w trudnych sprawach. Najwięcej z nich łączyło się z kwestiami odnoszącymi się do prześladowań i zasad przyjmowania upadłych do Kościoła. Wyjątkiem jest pierwszy z zachowanych listów Cypriana, dotyczący zupełnie innego zagadnienia, związanego z postępowaniem Geminiusza Wiktora, biskupa Furni na terenie dzisiejszej Tunezji.

Sprawa jest świadectwem bardzo radykalnego podejścia pierwotnego Kościoła, przynajmniej w Afryce Północnej, do angażowania się duchownych w kwestie materialne. Reakcja Cypriana była związana z faktem wyznaczenia przez biskupa Furni prezbitera Geminiusza Faustyna na prawnego opiekuna swojego testamentu ${ }^{7}$. Cyprian potępił we wspomnianym liście takie zachowanie, podkreślając, że kapłani zostali ustanowieni do posługi duchowej, dlatego powinni być wyłącznie sługami ołtarza i oddawać się modlitwie (non nisi altari et sacrificiis deservire et precibus atque orationibus vacare debeant), a nie myśleć o sprawach tego świata ${ }^{8}$. Mieli się utrzymywać jedynie z honorowych darów, będących swoistą dziesięciną pochodzącą z dochodów członków wspólnoty wiernych.

Swoje stanowisko Cyprian uzasadniał, powołując się na argumentację zarówno biblijną, jak i na przepisy ówczesnego prawa kościelnego. Najpierw przytoczył fragment 2 Listu św. Pawła do Tymoteusza, zakazujący żołnierzowi Boga zajmowania się sprawami światowymi (por. $2 \mathrm{Tm}$ 2,4), a także odwołał się do starotestamentalnej tradycji dotyczącej pokolenia Lewiego, które nie otrzymało w dziedzictwo posiadłości i nie zajmowało się uprawą ziemi, ale wyłącznie oddawało się służbie Bożej ${ }^{9}$. Następnie przywołał rozporządzenie lokalnego synodu, który miał miejsce najprawdopodobniej za biskupa Donata (246-248). Orzeczenie tego zgromadzenia biskupów było niezwykle rygorystyczne: „nasi poprzednicy [...] postanowili, aby nikt z braci odchodzących z tego świata, nie ustanawiał kogoś z kleru na opiekuna swego testamentu; a jeśliby to uczynił, aby za spokój jego duszy ani nie składać ofiar, ani też odprawiać modlitw. Nie zasługuje bowiem, aby przy ołtarzu Boga był wymieniany w modlitwie kapłańskiej ten, kto od ołtarza chciał odwoływać kapłanów i inne sługi Boże"10.

Interpretacja tego kanonu przez Cypriana jest literalna, jednoznaczna i nieodwołalna: za biskupa Geminiusza Wiktora, który ją złamał, nie należy składać ofiary eucharystycznej ani modlić się w kościele. Cyprian określił powyższą ustawę jako świętą i konieczną (decretum religiose et necessarie factum), i nakazał na jej podstawie ukarać wspomnianego biskupa ${ }^{11}$. Miała to być przestroga na przyszłość dla wszystkich duchownych.

\footnotetext{
6 Biskupi Afryki spotykali się na synodach w Kartaginie dwa razy w roku: wiosną i jesienią. Cyprian szanował ich autonomię, ale zwyczajem tamtejszego episkopatu było dążenie do wypracowania wspólnego stanowiska wobec problemów duszpasterskich występujących w różnych wspólnotach, tym bardziej, że biskup Kartaginy uważany był za głowę Kościoła w Afryce. Por. P. Zmire, Recherches sur la collégialité épiscopale dans l'Église d'Afrique, „Recherches Augustiniennes”, 7/1971, s. 27; A.G. Hamman, op. cit., s. 29; T. Maier, L'idée de conciliarité ou de synodalité aux conciles des $\mathrm{II}^{\mathrm{e}}$ et III ${ }^{\mathrm{e}}$ siècles, Toulouse 1993, s. 139; D. Arnauld, Histoire du christianisme en Afrique. Les sept premiers siècles, Paris 2001, s. 78-79; G.D. Dunn, Cyprien of Carthage and the Episcopal Synod of Late 254, „Revue des Études Augustiniennes”, 48/2002, s. 238-239. 245-246.

7 Por. M. Bogucki, op. cit., s. 210-212.

8 Por. Cyprianus, Epistula 1, 1, CSEL 3/2, s. 465, PSP 1, s. 27.

9 Por. ibidem, CSEL 3/2, s. 465-466, PSP 1, s. 27-28.

10 Ibidem, 1, 2, CSEL 3/2, s. 466: antecessores nostri [...] censuerunt ne quis frater excedens ad tutelam vel curam clericorum nominaret, ac si quis hoc fecisset, non offerretur pro eo nec sacrificium pro dormitione eius celebraretur. Neque enim apud altare Dei meretur nominari in sacerdotum prece qui ab altari sacerdotes et ministros voluit avocari, PSP 1, s. 28.

11 Por. ibidem, CSEL 3/2, s. 467, PSP 1, s. 28.
} 
W opisanej sytuacji uderza rygoryzm zarówno lokalnego północnoafrykańskiego prawa synodalnego, jak i samego Cypriana w kwestiach dotyczących moralności osób duchownych, zwłaszcza ich stosunku do dóbr materialnych. Dla wspomnianego biskupa nie ma żadnego usprawiedliwienia, a kara jest tak dotkliwa, jakby chodziło o nieodpuszczalne grzechy. Zaangażowanie w sprawy spadkowe i realizację rozporządzeń testamentalnych w wypadku osoby duchownej jest tu traktowane jak grzech, który sprowadza śmierć, sprawiający, że modlitwa za kogoś, kto go popełnił, nie ma już sensu (por. 1 J 5,16). Zdarzenie pokazuje, jak ważną rolę odgrywała za czasów Cypriana postawa ubóstwa duchowieństwa. Łączy się z nią kwestia działalności charytatywnej i pomocy ubogim, która jest przedmiotem innych listów Cypriana i wiąże się również z rygorystycznymi zaleceniami.

\section{Wszystkie pieniądze, które trafią do rąk duchownych, należy przeznaczyć dla potrzebujących $^{12}$}

Charakterystycznym rysem osobowości Cypriana była jego wrażliwość na potrzeby ludzi, którzy znaleźli się w trudnej sytuacji. Dał żywy przykład tej postawy, rozdając większość własnych dóbr po swoim nawróceniu, a także organizując dzieła miłosierdzia wobec ofiar zarazy w latach 252-254, czym z pewnością zyskał sobie popularność wśród wiernych ${ }^{13}$.

Podobnych zachowań wymagał jako biskup od podległego mu duchowieństwa. Ubóstwu duchownych powinna - w przekonaniu Cypriana - towarzyszyć ciągła troska o ubogich, potrzebujących i więźniów. Biskup akcentował tę kwestię jako naczelną w liście 5, napisanym do swojego duchowieństwa z miejsca ukrycia podczas prześladowań w $250 \mathrm{r}$. Prosił, aby na potrzeby wspomnianych osób przeznaczyć pieniądze, które trafią do rąk duchownych ${ }^{14}$. Użyta w tej zachęcie przydawka „wszystkie” (omnis) nie jest - jak się wydaje - przejawem retorycznej przesady, ale wyrazem radykalizmu wezwania wynikającego z Ewangelii, czego przykładem był „wdowi grosz”, czyli wszystko, co kobieta przedstawiona w przypowieści Jezusa miała na swoje utrzymanie (por. Mk 12,41-44, Łk 21,1-4).

W podobnym tonie Cyprian zwracał się do prezbiterów, aby w szczególny sposób opiekowali się ubogimi, zwłaszcza tymi, którzy zostali mocno doświadczeni przez prześladowania, a mimo to zachowali wiarę ${ }^{15}$. Świadectwem troski o wiernych, którzy znaleźli się w trudnej sytuacji, jest informacja zachowana w liście 62, skierowanym do biskupów gmin chrześcijańskich dotkniętych napaścią barbarzyńców. Cyprian przesłał wraz z listem sumę stu tysięcy sesterców ${ }^{16}$, zebranych wśród duchowieństwa i wiernych w kościele, z prośbą o wykupienie pojmanych chrześcijan ${ }^{17}$.

\footnotetext{
12 Por. ibidem, 5, 1, CSEL 3/2, s. 478-479: his qui pauperes et indigentes laborant et tamen in Domino perseverant, peto nihil desit, cum summula omnis quae redacta est illic sit apud clericos distributa propter eiusmodi casus, ut haberent plures unde ad necessitates et pressuras singulorum operari possint, PSP 1, s. 38.

13 Por. L. Mateja, Oblicza miłosierdzia. Historyczne uwarunkowania rozwoju doktryny o miłosierdziu. Studium dziet Tertuliana i świętego Cypriana, Kraków 2003, s. 194-195.

14 Por. Cyprianus, Epistula 5, 1, CSEL 3/2, s. 478-479, PSP 1, s. 38.

15 Por. ibidem, 14, 2, CSEL 3/2, s. 510-511, PSP 1, s. 61-62. Zob. L. Mateja, op. cit., s. 203; R. Pankiewicz, Pieniądz w działalności publicznej św. Cypriana, „Vox Patrum”, 10/1990, t. 19, s. 675.

16 Brązowa moneta rzymska o wadze 25-30 gramów.

17 Por. Cyprianus, Epistula 62, 3, CSEL 3/2, s. 700, PSP 1, s. 202; idem, De opere et eleemosynis 7, wyd. G. Hartel, Wien 1868, CSEL 3/1, s. 378-379; Cyprian, O uczynku i jałmużnach, tłum. J. Czuj, Poznań 1937, POK 19, s. 332; ibidem, 25, CSEL 3/1, s. 393-394, POK 19, s. 345-346. Zob. M. Bogucki, op. cit., s. 210; T. Kaczmarek,
} 
Jak wynika ze wskazanych wyżej przykładów, Cyprian miał zwyczaj kierowania do duchowieństwa popartych własnym świadectwem próśb o oddawanie ubogim i potrzebującym jak najwięcej, a nawet wszystkiego, co się posiada. W tych zachętach biskupa Kartaginy łączy się harmonijnie postawa miłosierdzia wobec ubogich z radykalizmem wymagań wobec osób duchownych, wezwanych do ewangelicznego ubóstwa.

\section{Trzeba dążyć za wszelką cenę do nawrócenia i poprawy buntownika, natomiast usunięcie go ze wspólnoty Kościoła ma być ostatecznością ${ }^{18}$}

Innym, obok bogacenia się, problemem duchowieństwa, sięgającym początków chrześcijaństwa, był brak posłuszeństwa wobec własnego biskupa. Wczesnym przykładem takiej postawy może być bunt we wspólnocie korynckiej przeciwko biskupowi z racji jego młodego wieku, o czym u schyłku I wieku wspominał w swoim liście biskup Rzymu Klemens ${ }^{19}$. Również w epistolografii Cypriana występują podobne sytuacje, pojawiające się zwłaszcza przy okazji samowolnego postępowania wobec lapsi. W liście 16 do prezbiterów i diakonów z 250 r. biskup Kartaginy, przebywający w ukryciu, skarżył się na pogardę duchownych wobec władzy biskupów, wyrażającą się w przywłaszczaniu sobie pełni władzy i przyjmowaniu upadłych do wspólnoty z Kościołem bez spełnienia odpowiednich warunków. Cyprian podkreślił, że właściwa praktyka obejmuje okres pokuty i publicznego zadośćuczynienia dla grzeszników, a powtórne przyjęcie do wspólnoty może odbyć się jedynie przez nałożenie rąk biskupa i duchowieństwa. Tymczasem dopuszczano ich do przyjmowania Eucharystii bez zgody biskupa i spełnienia powyższych warunków. Postępującym w ten sposób duchownym Cyprian groził surowymi karami: zakazem sprawowania eucharystycznej ofiary oraz koniecznością publicznego wyznania grzechu nieposłuszeństwa przed biskupem i całym ludem ${ }^{20}$.

Nieposłuszeństwo wobec biskupa było także problemem dotykającym diakonów. W liście 3 z 249 r. biskup Kartaginy zwrócił się do bliżej nieznanego biskupa Rogacjana z pouczeniem, jak ma postąpić z diakonem, który w nieopisanych okolicznościach znieważył go i obraził obelgami ${ }^{21}$. Zalecił w tej i podobnych sytuacjach bezwzględną i niezwłoczną surowość. Według Cypriana Rogacjan nie musiał zwlekać i radzić się go, ale powinien na mocy urzędu biskupiego natychmiast i z całą stanowczością ukarać krnąbrnego diakona według własnego uznania (pro episcopatus vigore et cathedrae auctoritate haberes potestatem qua posses de illo statim vindicari $)^{22}$.

Organizacja dzieł charytatywnych Kościoła w Kartaginie pod kierunkiem św. Cypriana, „Studia Włocławskie”, 2/1999, s. 125-131; V. Hunink, St Cyprian, a Christian and Roman Gentleman, w: Cyprian of Carthage. Studies in His Life, Language and Thought, red. H. Bekker, P. van Geest, H. van Loon, Leuven-Paris-Walpole 2010, s. 32-33; M. Wysocki, Model doskonałego chrześcijanina w pismach św. Cypriana z Kartaginy, „Vox Patrum”, 30/2010, t. 55 , s. 707-708.

18 Por. Cyprianus, Epistula 3, 3, CSEL 3/2, s. 471-472: oportet [...] agere audaciae suae paenitentiam [...] si ultra te contumeliis suis exacerbaverit et provocaverit, fungeris contra eum potestatem honoris tui, ut eum vel deponas vel abstineas, PSP 1, s. 32-33.

19 Por. Clemens Romanus, Epistula ad Corinthios 1, 1, wyd. A. Jaubert, Paris 1971, „Sources Chrétiennes”, t. 167, s. 98-100; Klemens Rzymski, List do Kościoła w Koryncie, tłum. A. Świderkówna, w: Ojcowie Apostolscy, Warszawa 1990, PSP 45, s. 23.

20 Por. Cyprianus, Epistula 16, 1-3, CSEL 3/2, s. 517-520, PSP 1, s. 66-68.

21 Por. M. Bogucki, op. cit., s. 212-214.

22 Por. Cyprianus, Epistula 3, 1, CSEL 3/2, s. 469, PSP 1, s. 31. 
Cyprian powołał się przy tym na argumentację starotestamentalną, przywołując nakaz ukarania śmiercią człowieka pysznego, który nie posłucha kapłana (por. Pwt 17,12) oraz przykłady surowych kar Bożych zesłanych na buntowników wobec Aarona (por. Lb 16,35) i Samuela (por. $1 \mathrm{Sm} \mathrm{8,7)23}$. Przytoczył również szereg nakazów oddawania czci kapłanom oraz zakazów złorzeczenia i okazywania im nieposłuszeństwa, zaczerpniętych zarówno ze Starego (por. Syr 7,21; 7,31), jak i Nowego Testamentu (por. Dz 23,4; Mt 8,4; J 18,23)²4. Zwrócił uwagę, że biskupów jako następców Apostołów powołał sam Bóg, a diakonów wybrali na swoje sługi biskupi, co nakłada na diakonów szczególny rodzaj posłuszeństwa wobec biskupów: ,jeśli nikt z nas [biskupów] nie może wystąpić przeciw Bogu, który ustanawia biskupów, tak też diakoni przez nas ustanowieni, nie mogą przeciw nam występować”25.

W dalszej części listu Cyprian zaproponował Rogacjanowi konkretny sposób postępowania wobec krnąbrnego diakona. Powinien on odpowiednio odpokutować i zadośćuczynić za swój czyn. Gdyby jednak nadal znieważał biskupa i występował przeciw niemu, należy takiemu diakonowi odebrać urząd i wykluczyć go z jedności kościelnej wraz z tymi osobami, które z nim współdziałały. Taka kara ma być jednak ostatecznościąa ${ }^{26}$. Według Cypriana odwołującego się w opisanej sytuacji do chrześcijańskiego miłosierdzia - należało dążyć za wszelką cenę do nawrócenia i poprawy buntownika, natomiast usunięcie go ze wspólnoty Kościoła miało być rozwiązaniem ostatecznym ${ }^{27}$. Przy okazji powyższych pouczeń Cyprian zwrócił uwagę, że pycha i nieposłuszeństwo wobec przełożonych są początkiem i pierwszym krokiem do schizmy, czego za wszelką cenę należy unikać28.

Powyższa kwestia ukazuje ponownie połączenie miłosierdzia z surowością w postawie biskupa Kartaginy, podobne do tego, jakie pojawiało się w przypadku stosunku do lapsi. Według Cypriana kara wobec nieposłusznego duchownego powinna mieć charakter naprawczy i być pozbawiona radykalizmu. W przypadku, gdyby nie spełniła swojej roli, należało zastosować skrajne środki.

\section{4. „Pyszni i zatwardziali zabijani są mieczem duchowym przez wydalenie ich z Ko- ściola"29}

W starożytnym Kościele pojawiały się niekiedy nadużycia przeciw czystości u osób ślubujących Bogu taką postawę. List 4 Cypriana, skierowany do biskupa Dionizjany - Pomponiusza, jest świadectwem podobnych problemów w jego czasach ${ }^{30}$. Biskup Kartaginy zareagował w nim na przypadki przyłapania dziewic, ślubujących pozostanie w tym stanie, w jednym łóżku z mężczyznami, wśród których był także diakon. Wszystkie przyznały się do spania

\footnotetext{
23 Por. ibidem.

24 Por. Cyprianus, Epistula 3, 2, CSEL 3/2, s. 470-471, PSP 1, s. 31-32.

25 Ibidem, 3, 3, CSEL 3/2, s. 471: Quod si nos aliquid audere contra Deum possumus qui episcopos facit, possunt et contra nos audere diaconi a quibus fiunt, PSP 1, s. 32.

26 Por. ibidem.

27 Por. R. Andrzejewski, Święty Cyprian z Kartaginy. Między karnością a łagodnościa w oparciu o zasadę jedności Kościoła, „Ateneum Kapłańskie”, 92/1979, s. 372-379; M. Wysocki, Przebaczenie w pismach św. Cypriana, „Verbum Vitae", 18/2010, s. 200-205; Mateja, Oblicza miłosierdzia, s. 199-204; J. Grzywaczewski, The Biblical Idea of Divine Mercy in the Early Church, Warszawa 2016, s. 255-258.

28 Por. Cyprianus, Epistula 3, 3, CSEL 3/2, s. 471-472, PSP 1, s. 33.

29 Ibidem, 4, 4, CSEL 3/2, s. 477, PSP 1, s. 36.

30 Por. M. Bogucki, op. cit., s. 214-218.
} 
z mężczyznami, ale równocześnie twierdziły, że zachowały dziewictwo ${ }^{31}$. Sytuacja przypomina prezbiterów, którzy zapewniali, że są w stanie zachować czystość, nawet mieszkając pod jednym dachem i śpiąc razem z agapetkami (virgines subintroductae) ${ }^{32}$. Cyprian, ustosunkowując się do kwestii wspomnianych dziewic, zdecydowanie zakazał ich wspólnego mieszkania z mężczyznami, ponieważ wzmaga to diabelskie pokusy i utrudnia zachowanie karności kościelnej. Jeżeli natomiast dziewice nie chcą lub nie mogą wytrwać w czystości, powinny wstąpić $\mathrm{w}$ związki małżeńskie, w przeciwnym razie gorszą innych ludzi ${ }^{33}$. Tym bardziej odnosi się to do prezbiterów i diakonów niezachowujących czystości. Mają oni czuwać nad wstrzemięźliwością innych, a sami nie potrafią jej dochować34.

Oprócz powyższych wskazówek moralnych, popartych argumentami biblijnymi (por. Ps 2,12; Ef 4,27; 1 Kor 8,13) ${ }^{35}$, Cyprian udzielił Pomponiuszowi bardzo konkretnych rad duszpasterskich ${ }^{36}$. Chwalił biskupa Dionizjany za to, że wykluczył z Kościoła diakona i wszystkich mężczyzn sypiających z dziewicami. Co do upadłych dziewic, zalecił surową pokutę i zakazał kontaktowania się z mężczyznami, z którymi ich przyłapano, z zastrzeżeniem, że gdyby powróciły później do owych mężczyzn lub dalej z nimi mieszkały, mają zostać ukarane z jeszcze większą surowością, a ich późniejsze ewentualne przyjęcie do Kościoła nie powinno być zbyt łatwe, chociaż Cyprian nie precyzuje, w jaki sposób miałoby się ono dokonać. Wszystkie wspomniane dziewice powinny także zostać dokładnie zbadane przez akuszerki i - jeżeli okazałoby się, że nie straciły dziewictwa - przyjęte do wspólnoty Kościoła. Gdyby okazało się jednak, że któraś z nich utraciła dziewictwo, musi zostać poddana surowej i długotrwałej pokucie jako cudzołożnica, która zdradziła Chrystusa. W przypadku, gdyby dziewice nie chciały w żaden sposób rozłączyć się z mężczyznami, powinny być na trwałe usunięte z Kościoła i pozbawione nadziei na życie wieczne i zbawienie: „Wtedy, gdy jeszcze istniało cielesne obrzezanie, takich zabijano mieczem, teraz gdy wiernych sług zaczęło obowiązywać obrzezanie duchowe, pyszni i zatwardziali zabijani są mieczem duchowym przez wydalenie ich z Kościoła. Nie mogą bowiem żyć poza nim, skoro dom Boga jest tylko jeden i poza Kościołem nikt nie może się zbawić. Nieposłuszni zaś giną, bo nie słuchają i nie dostosowują się do zbawiennych nakazów"37.

Należy podkreślić, że głównym argumentem Cypriana za tak surową karą jest nieposłuszeństwo biskupom i kapłanom, w czym wyraża się eklezjalne myślenie Kartagińczyka, upatrujące możliwość zbawienia jedynie we wspólnocie Kościoła Chrystusowego ${ }^{38}$. Podobnie jak w przypadku nieposłuszeństwa biskupowi, w opisanej powyżej sytuacji złamania ślubu

\footnotetext{
31 Por. Cyprianus, Epistula 4, 1, CSEL 3/2, s. 472-473, PSP 1, s. 33-34.

32 Por. B. Czyżewski, Geneza życia zakonnego. Studium historyczne, „Studia Gnesnensia”, 20/2006, s. 95; S. Longosz, Pisma przeciw synezaktom, „Vox Patrum”, 13-15/1993-1995, t. 24-29, s. 337-365.

33 Por. Cyprianus, Epistula 4, 2, CSEL 3/2, s. 473-474, PSP 1, s. 35.

34 Por. ibidem, 4, 3, CSEL 3/2, s. 475, PSP 1, s. 35-36.

35 Por. ibidem, 4, 2, CSEL 3/2, s. 473-474, PSP 1, s. 34-35.

36 Por. ibidem, 4, 4, CSEL 3/2, s. 475-477, PSP 1, s. 36-37.

37 Ibidem, CSEL 3/2, s. 476-477: Et tunc quidem gladio occidebantur, quando adhuc et circumcisio carnalis manebat: nunc autem quia circumcisio spiritalis esse ad fideles servos Dei coepit, spiritali gladio superbi et contumaces necantur, dum de ecclesia eiciuntur. Neque enim vivere foris possunt, cum domus Dei una sit et nemini salus esse nisi in ecclesia possit. Indisciplinatos autem perire, dum non audiunt nec obtemperant salubribus praeceptis, PSP 1, s. 36-37.

38 Por. L. Dattrino, L'ecclesiologia di San Cipriano nel contesto della chiesa del III secolo, „Lateranum”, 50/1984, s. $127-150$.
} 
czystości przez osoby poświęcone Bogu Cyprian łączył miłosierdzie z surowością: należy zastosować dotkliwą pokutę, jeżeli jednak nie odniesie ona pożądanego skutku, pozostaje radykalna kara usunięcia z Kościoła. Samo wykluczenie z Kościoła bez dania szansy nawrócenia byłoby - zdaniem biskupa Kartaginy - przejawem złej postawy duszpasterskiej.

\section{Glupota, którą można wybaczyćc 39}

Wśród listów Cypriana skierowanych w sprawie zaniedbań osób duchownych jeden dotyczy ważnej kwestii dyscyplinarnej odnoszącej się do postawy określanej we wczesnochrześcijańskich katalogach herezji mianem akwarianizmu ${ }^{40}$. Chodzi o list 63 do Cecyliusza, biskupa Bilthy, będący świadectwem nadużyć związanych ze sposobem sprawowania eucharystycznej ofiary. Cyprian piętnował w nim zwyczaj praktykowany przez niektórych biskupów. Wbrew tradycji, przy składaniu ofiary nie używali oni wina, a jedynie wody ${ }^{41}$.

List ma charakter obszernego traktatu teologicznego, wykazującego na podstawie obszernej argumentacji biblijnej, dlaczego do ważności Eucharystii konieczne jest używanie wina zmieszanego z wodą. Podstawowe uzasadnienie tej liturgicznej praktyki to słowa samego Chrystusa „Ja jestem prawdziwym krzewem winnym” (J 15,1) ${ }^{42}$ oraz Jego zachowanie podczas ostatniej wieczerzy ${ }^{43}$. Według Cypriana teologiczne znaczenie tego zwyczaju jest następujące: „Ponieważ Chrystus niósł nas wszystkich i grzechy nasze, dlatego widzimy, że woda oznacza lud, wino zaś krew Chrystusa. Gdy więc w kielichu wino z wodą jest zmieszane, to lud staje się jedno z Chrystusem i rzesza wiernych jednoczy się i łączy z Tym, w którego uwierzyła. [...] Jeśli bowiem ktoś ofiarowuje samo wino, to krew Chrystusa pozostaje bez nas, jeżeli zaś ofiarowuje się samą tylko wodę, to lud jest bez Chrystusa. Skoro zaś oba się zmiesza i przez to wzajemnie się złączy, dopełnia się duchowa i niebiańska tajemnica"44.

Szczególnie interesujące jest powoływanie się przez biskupa Kartaginy na teksty Starego Testamentu i ich wyszukana, niekiedy zaskakująca interpretacja alegoryczna, niespotykana często w tym czasie w łacińskojęzycznej egzegezie. Można podejrzewać w tym zjawisku wpływ środowiska aleksandryjskiego. Biskup Kartaginy uważał na przykład, że Noe, który nie pił wody, ale wino, a nawet upijał się nim (por. Rdz 9,20-27), jest figurą męki Pana i przelania przez Niego krwi ${ }^{45}$. Typem Chrystusa, który złożył w ofierze Bogu chleb

\footnotetext{
39 Por. Cyprianus, Epistula 63, 17, CSEL 3/2, s. 715: potest simplicitati eius de indulgentia Domini venia concedi, PSP 1, s. 212. W. Szołdrski przełożył użyty w tym kontekście przez Cypriana łaciński termin simplicitas jako ,,prostota”, ale zdecydowanie bardziej pasuje tu znaczenie „naiwność” czy wręcz ,głupota”.

40 Por. Filastrius Bresciensis, Diversarum hereseon liber 77, wyd. F. Heylen, Turnhout 1957, „Corpus Christianorum. Series Latina”, t. 9, s. 249. Zob. B. Renaud, Eucharistie et culte eucharistique selon Saint Cyprien, Louvain 1967, s. 29-32; W.H. Bates, Saint Cyprian and the “Aquarians”, „Studia Patristica”, 15/1975, s. 511-514; P. Pietrusiak, Materia Eucharystii w Kościele pierwszych wieków, „Resovia Sacra. Studia Teologiczno-Filozoficzne Diecezji Rzeszowskiej”, 18-20/2011-2013, s. 60-61.

41 Por. J. Krzyżaniak, Materia i forma Eucharystii według św. Cypriana, „Roczniki Teologiczno-Kanoniczne”, 5/1958, z. 3, s. 27-47; T. Kaczmarek, Tajemnica kielicha Pańskiego wedtug Listu 63 św. Cypriana, w: Pokarm nieśmiertelności. Eucharystia w życiu pierwszych chrześcijan, red. W. Myszor, E. Stanula, Katowice 1987, s. 144-155; D. Drążek, Ofiara Eucharystii jako zobowiązanie do jedności i świętości w pismach św. Cypriana, „Verbum Vitae”, 8/2005, s. 151-162.

42 Por. Cyprianus, Epistula 63, 1-2, CSEL 3/2, s. 701-702, PSP 1, s. 202-203.

43 Por. ibidem, 63, 14-17, CSEL 3/2, s. 712-715, PSP 1, s. 210-212.

44 Ibidem, 63, 13, CSEL 3/2, s. 711-712, PSP 1, s. 209-210.

45 Por. ibidem, 63, 3, CSEL 3/2, s. 702, PSP 1, s. 203-204.
} 
i wino, czyli swoje ciało i krew, był - zdaniem Cypriana - również kapłan Melchizedek, król Salemu (por. Rdz 14,18) ${ }^{46}$.

Cyprian podkreślał, że ilekroć Pismo Święte wspomina tylko o wodzie (por. Iz 48,21; J 7,37-39), wskazuje na chrzest, a nie na Eucharystię, podczas której kielich napełnia się mieszaniną wina i wody ${ }^{47}$. Słowa Chrystusa skierowane do Samarytanki przy studni „Każdy, kto pije tę wodę, znowu pragnąć będzie, kto jednak napije się wody, którą ja mu dam, na wieki pragnąć nie będzie” (J 4,13) - odnoszą się, w przekonaniu biskupa Kartaginy, do chrztu, który przyjmuje się jeden raz i nie ponawia, podczas gdy kielich Pana pije się w Kościele wielokrotnie ${ }^{48}$. Koronnym dowodem ustanawiającym tradycję używania wina do składania ofiary eucharystycznej były dla Cypriana słowa Jezusa z ostatniej wieczerzy w przekazie św. Pawła: „Ten kielich jest nowy przymierzem we krwi mojej” (1 Kor 11,25). Tej tradycji, pochodzącej od samego Zbawiciela i Apostołów, nikt zmienić nie może ( $a b$ evangelicis autem pareceptis omnino non recedendum esse; por. Ga 1,6-9) ${ }^{49}$. Akwarianie postępujący w ten sposób nie idą za Chrystusem ${ }^{50}$, ale zachowują się odwrotnie niż Jezus w Kanie Galilejskiej: On zamienił wodę w wino, oni czynią z wina wodę ${ }^{51}$.

Mimo krytyki akwarianizmu, który był postawą sprzeczną z tradycją Biblii i pierwotnego Kościoła, Cyprian nie określił go terminem haeresis. Mówił jednak o nadużyciu (usurpatum $)^{52}$ i o błędzie (error) $)^{53}$, który to termin był do IV w. używany jako synonim terminu haeresis ${ }^{54}$. Nakazywał zachowanie prawa Ewangelii i tradycji Pańskiej (lex evangelica et traditio dominica) ${ }^{55}$, ale nie nakładał surowych kar na tych, którzy dopuścili się praktyk akwariańskich. W duchu miłosierdzia nazywał postawę tych biskupów, którzy hołdowali akwarianizmowi, głupotą lub naiwnością (simplicitas), którą można wybaczyćc5 , gdyż było to - jego zdaniem - postępowanie płynące z niewiedzy (ignoranter) ${ }^{57}$. To łagodne odniesienie Cypriana do zachowania akwarian wynikało - jak się wydaje - nie z lekceważenia problemu, który został przedstawiony w liście z całą teologiczną powagą, ale z przekonania, że praktyki

\footnotetext{
46 Por. ibidem, 63, 4, CSEL 3/2, s. 703-704, PSP 1, s. 204-205. Według Cypriana zapowiedź kielicha Pana zawierającego mieszaninę wody i wina zawierały także słowa włożone przez Salomona w usta upersonifikowanej Mądrości: „Przyjdźcie i jedzcie z mych chlebów i pijcie wino, które wam zmieszałam” (por. Prz 9,1-2). Figurą wina w kielichu, będącego krwią Pana, jest też błogosławieństwo, jakie otrzymał Juda: „obmyje w winie szatę swoją i we krwi owocu winnego płaszcz swój” (Rdz 49,11) oraz zapowiedź męki Pańskiej u proroka Izajasza: „Czemu czerwone są szaty twoje, a odzienie twoje jak przy deptaniu w prasie pełnej winogron i ich wyciskaniu" (Iz 63,2). Por. ibidem, 63, 5-7, CSEL 3/2, s. 704-705, PSP 1, s. 205.

47 Por. ibidem, 63, 8-9, CSEL 3/2, s. 706-708, PSP 1, s. 206-207.

48 Por. ibidem, 63, 8, CSEL 3/2, s. 707, PSP 1, s. 207.

49 Por. ibidem, 63, 10, CSEL 3/2, s. 709, PSP 1, s. 208.

50 Por. ibidem, 63, 14. 18, CSEL 3/2, s. 712. 716, PSP 1, s. 210, 213.

51 Por. ibidem, 63, 12, CSEL 3/2, s. 710-711, PSP 1, s. 209.

52 Por. ibidem, 63, 11, CSEL 3/2, s. 709, PSP 1, s. 208.

53 Por. ibidem, 63, 18, CSEL 3/2, s. 715, PSP 1, s. 212.

54 Por. Filastrius Brisciensis, Diversarum hereseon liber, Praefatio 1, CCL 9, s. 217: De hereseon diversa pestilentia variisque erroribus qui ab origine mundi emerserint et sub Iudaeis defluxerint. Zob. M. Szram, ,Varii errores qui ab origine mundi emerserunt". The Semantic Scope of the Term "Heresy" in Philastrius' of Brescia "Diversarum hereseon liber”, ,Vox Patrum”, 37/2017, t. 68, s. 315-325.

55 Por. Cyprianus, Epistula 63, 17, CSEL 3/2, s. 715, PSP 1, s. 212; ibidem, 63, 2, CSEL 3/2, s. 702, PSP 1, s. 203.

56 Por. ibidem, 63, 17, CSEL 3/2, s. 715, PSP 1, s. 212. Zob. W. Myszor, Zagadnienie herezji w listach św. Cypriana, „Studia Theologica Varsaviensia”, 9/1971, z. 1, s. 171-174.

57 Por. Cyprianus, Epistula 63, 1, CSEL 3/2, s. 701, PSP 1, s. 203; ibidem, 63, 17, CSEL 3/2, s. 715, PSP 1, s. 212.
} 
akwariańskie wynikały z jakiegoś ograniczenia władzy rozumu, które mogło powodować niepełną świadomość popełnianego czynu. Cyprian zaznaczył zdecydowanie, że obszerne pouczenie, jakie dał w swoim liście na temat sposobu sprawowania Eucharystii, kończy ten okres miłosierdzia i odtąd nie będzie można już wymówić się niewiedzą ${ }^{58}$. M. Bogucki sugeruje, że brak surowości w stanowisku Cypriana wynikał z chęci uzyskania przychylności akwarian i skierowania ich na właściwą drogę przez spokojne wyjaśnienie problemu, a nie straszenie karami ${ }^{59}$. Biskup Kartaginy próbował także zrozumieć i usprawiedliwić ich postawę przypuszczeniem, że niektórzy wierni wstydzili się rano przyjąc krew Pańską, by nie zdradzić się zapachem wina i nie wzbudzić podejrzeń o skłonność chrześcijan do pijaństwa. Zachęcał jednak do odrzucenia takich obaw i niekierowania się w tak istotnych sprawach względami ludzkimi ${ }^{60}$.

\section{Podsumowanie}

Przedstawione na przykładzie korespondencji Cypriana problemy osób duchownych, występujące w Kościele w Afryce w połowie III w., obejmowały zarówno zagadnienia, które powtarzały się później w różnych epokach dziejów Kościoła (bogacenie się, nieposłuszeństwo wobec władz kościelnych, złamanie ślubu czystości), jak i specyficzne kwestie, charakterystyczne dla konkretnego miejsca i czasu (herezja akwarian). Ustosunkowując się w listach do powyższych spraw, biskup Kartaginy jawi się jako pasterz świadomy roli przełożonego odpowiedzialnego za świętość Kościoła - jedynej wspólnoty wiary, w której można osiągnąć zbawienie. Zachowana korespondencja ukazuje Cypriana jako rządcę aktywnego, wymagającego od siebie i innych, wrażliwego na potrzeby biednych, zatroskanego o moralne postawy duchownych, występującego w roli doradcy wobec trudnych sytuacji pojawiających się w sąsiednich diecezjach.

W większości opisanych w listach spraw, dotyczących zachowywania ubóstwa i czystości, Cyprian łączył postawy miłosierdzia i radykalizmu. W duchu miłosierdzia dawał szansę nawrócenia przez surową pokutę, a gdy to nie przynosiło pożądanego skutku, posuwał się do ostatecznej kary wyłączenia z Kościoła. Było to postępowanie podobne do tego, jakie stosował wobec lapsi. Dwie z opisanych sytuacji wskazują jednak na inne, dość zaskakujące reakcje biskupa Kartaginy. W kwestii angażowania się osób duchownych, zwłaszcza biskupów, w sprawy spadkowe, Cyprian był bezlitosnym rygorystą, co wiązało się z surowym afrykańskim prawem synodalnym tego okresu. Natomiast w ważnej kwestii liturgicznej o podłożu dogmatycznym, jaką było zachowanie akwarian, Cyprian - nie lekceważąc bynajmniej powagi popełnianego przez nich błędu i przestrzegając przed nim na przyszłość - skłaniał się ku potraktowaniu ich postępowania jako zwykłej głupoty, zasługującej na wybaczenie.

\footnotetext{
58 Por. ibidem, 63, 17, CSEL 3/2, s. 715, PSP 1, s. 212.

59 Por. M. Bogucki, op. cit., s. 201-202.

60 Por. Cyprianus, Epistula 63, 15, CSEL 3/2, s. 713-714, PSP 1, s. 211.
} 


\section{Bibliografia}

\section{Źródla}

Clemens Romanus, Epistula ad Corinthios, wyd. A. Jaubert, Paris 1971, „Sources Chrétiennes", t. 167; Klemens Rzymski, List do Kościoła w Koryncie, tłum. A. Świderkówna, w: Ojcowie Apostolscy, Warszawa 1990, „Pisma Starochrześcijańskich Pisarzy”, t. 45, s. 23-55.

Cyprianus, De lapsis, wyd. G. Hartel, Wien 1868, „Corpus Scriptorum Ecclesiasticorum Latinorum”, t. 3/1, s. 237-264; Cyprian, O upadtych, tłum. J. Czuj, Poznań 1937, „Pisma Ojców Kościoła", t. 19, s. 196-223.

Cyprianus, De opere et eleemosynis, wyd. G. Hartel, Wien 1868, „Corpus Scriptorum Ecclesiasticorum Latinorum”, t. 3/1, s. 373-394; Cyprian, O uczynku i jałmużnach, tłum. J. Czuj, Poznań 1937, „Pisma Ojców Kościoła”, t. 19, s. 327-347.

Cyprianus, Epistulae, wyd. G. Hartel, Wien 1871, „Corpus Scriptorum Ecclesiasticorum Latinorum”, t. 3/2; Św. Cyprian, Listy, tłum. W. Szołdrski, Warszawa 1969, „Pisma Starochrześcijańskich Pisarzy", t. 1.

Filastrius Bresciensis, Diversarum hereseon liber, wyd. F. Heylen, Turnhout 1957, „Corpus Christianorum. Series Latina", t. 9.

\section{Opracowania}

Andrzejewski R., Święty Cyprian z Kartaginy. Między karnością a łagodnościa w oparciu o zasade jedności Kościoła, „Ateneum Kapłańskie”, 92/1979, s. 372-379.

Arnauld D., Histoire du christianisme en Afrique. Les sept premiers siècles, Paris 2001.

Bogucki M., Problemy duszpasterskie w listach św. Cypriana, „Studia Theologica Varsaviensia", 9/1971, nr 1, s. 191-224.

Bates W.H., Saint Cyprian and the "Aquarians”, „Studia Patristica”, 15/1975, s. 511-514.

Czuj J., Święty Cyprian na tle epoki, „Ateneum Kapłańskie”, 36/1935, s. 113-135.

Czyżewski B., Geneza życia zakonnego. Studium historyczne, „Studia Gnesnensia”, 20/2006, s. $87-104$.

Dattrino L., L'ecclesiologia di San Cipriano nel contesto della chiesa del III secolo, „Lateranum", 50/1984, s. $127-150$.

Drążek D., Ofiara Eucharystii jako zobowiazanie do jedności i świętości w pismach św. Cypriana, „Verbum Vitae”, 8/2005, s. 151-162.

Dunn G.D., Cyprien of Carthage and the Episcopal Synod of Late 254, „Revue des Études Augustiniennes", 48/2002, s. 229-247.

Fitzgerald P.J., A Model for Dialogue: Cyprian of Carthage on Ecclesial Discernment, „Theological Studies”, 59/1998, s. 236-253.

Grzywaczewski J., Great Persecutions and the Reconciliation of the Lapsi, Warszawa 2015. Grzywaczewski J., The Biblical Idea of Divine Mercy in the Early Church, Warszawa 2016. Hamman A.G., Życie codzienne w Afryce Pótnocnej w czasach św. Augustyna, tłum. M. Stafiej-Wróblewska, E. Sieradzińska, Warszawa 1989.

Hunink V., St Cyprian, a Christian and Roman Gentleman, w: Cyprian of Carthage. Studies in His Life, Language and Thought, red. H. Bekker, P. van Geest, H. van Loon, Leuven-Paris-Walpole 2010, s. 29-41. 
Kaczmarek T., Organizacja dzieł charytatywnych Kościoła w Kartaginie pod kierunkiem św. Cypriana, „Studia Włocławskie”, 2/1999, s. 125-131.

Kaczmarek T., Tajemnica kielicha Pańskiego według Listu 63 św. Cypriana, w: Pokarm nieśmiertelności. Eucharystia w życiu pierwszych chrześcijan, red. W. Myszor, E. Stanula, Katowice 1987, s. 144-155.

Krzyżaniak J., Materia i forma Eucharystii wedtug św. Cypriana, „Roczniki Teologiczno-Kanoniczne", 5/1958, z. 3, s. 27-47.

Longosz S., Pisma przeciw synezaktom, „Vox Patrum”, 13-15/1993-1995, t. 24-29, s. 337-365.

Maier T., L'idée de conciliarité ou de synodalité aux conciles des II et III siècles, Toulouse 1993.

Mateja L., Oblicza miłosierdzia. Historyczne uwarunkowania rozwoju doktryny o miłosierdziu. Studium dziel Tertuliana i świętego Cypriana, Kraków 2003.

Michalski M., Wstęp, w: Św. Cyprian, Listy, tłum. W. Szołdrski, Warszawa 1969, „Pisma Starochrześcijańskich Pisarzy", t. 1, s. 9-26.

Myszor W., Zagadnienie herezji w listach św. Cypriana, „Studia Theologica Varsaviensa”, 9/1971, z. 1, s. 147-190.

Pankiewicz R., Pieniądz w działalności publicznej św. Cypriana, „Vox Patrum”, 10/1990, t. 19 , s. 671-680.

Pietrusiak P., Materia Eucharystii w Kościele pierwszych wieków, „Resovia Sacra. Studia Teologiczno-Filozoficzne Diecezji Rzeszowskiej”, 18-20/2011-2013, s. 47-63.

Renaud B., Eucharistie et culte eucharistique selon Saint Cyprien, Louvain 1967.

Szram M., "Varii errores qui ab origine mundi emerserunt". The Semantic Scope of the Term “Heresy” in Philastrius' of Brescia “Diversarum hereseon liber”, „Vox Patrum”, 37/2017, t. 68, s. 315-325.

Wysocki M., Model doskonatego chrześcijanina w pismach św. Cypriana z Kartaginy, „Vox Patrum", 30/2010, t. 55, s. 699-720.

Wysocki M., Przebaczenie w pismach św. Cypriana, „Verbum Vitae”, 18/2010, s. 187-211.

Zmire P., Recherches sur la collégialité épiscopale dans l'Église d'Afrique, „Recherches Augustiniennes", 7/1971, s. 3-72. 